\author{
Vol: 2, Issue: 12 \\ December/2021 \\ DOI: http://dx.doi.org/10.47742/ijbssr.v2n12p2 \\ https://ijbssrnet.com/index.php/ijbssr
}

\title{
Digital revolution and place of printed books
}

\author{
Maciej Zweiffel \\ Institute of Journalism and Social Communication \\ Orcid: https://orcid.org/0000-0002-4010-3907
}

Email: maciej.zweiffel@uj.edu.pl

Poland

\section{A R T I C L E I N F O \\ Article history: \\ Received: \\ Dec 2021 \\ Revised: \\ Dec 20,2021 \\ Accepted: \\ Dec 25,2021 \\ Publication: Dec 31,2021 \\ DOI: $10.47742 /$ ijbssr.v2n12p2}

https://creativecommons.org/licenses/by/4.0/

\begin{abstract}
A B S T R A C T
"Digital-first" seems to be a crucial idea of our time. From the practical, economic, and even ecological point of view printed books are not the best solution. But still, this practice exists. This survey aims to answer, why in the digital environment occurs the textual niche. Is it a kind of relic or something which is deeply connected with human reading comprehension and the quality of text experience? To solve this problem will be used case study and cognitive methods. The crucial question for the presented paper is whether printed (codex) books and their reading means a form of distributing texts which will be progressively declining under pressure in the digital revolution $(Q 1)$. To answer this question, it is necessary to describe the current situation of traditional printing and also raise the question of printed documents especially printed and codex books have any features which cannot be replaced by online publishing (Q2). In the second question, one should take into account the cultural and subjective context of reading or possessing printed books.
\end{abstract}

Keywords: digitalisation, extensive reading, hybrid reading, intensive reading, printed book, publishing market, typography

\section{Opening remarks}

The digital revolution in almost every area of human life is a fact. There is no question that trade, business, goods production, engineering, not to mention interpersonal communication, and broadcasting are deeply connected with IT technology.

This process is also being observed in the publishing area. The slogan "Digital first" may soon be replaced by "Digital only", because as it was stressed by Eric Pearson, Chief Information Officer of InterContinental Hotels Group "It's no longer the big beating the small, but the fast beating the slow." (Jones, 2018). And printing a book because of its solid, material form which involved printing industry and delivery system is simply much slower than internet publishing.

There is a lot of evidence of the IT revolution and replacing the process of printing by digital publishing, but one of the most striking was probably the announcement that the 2010 edition of "Encyclopaedia Britannica" was to be the last printed version (Pepitone, 2012). "The world standard of knowledge since 1768 " as the Britannica's catchphrase says ended its career on bookshelves and moved out to the digital world.

New media and its impact on societies can also be seen in reading and writing abilities literacy. Nowadays one of the main goals of education is not only to learn reading and writing but learn to do it via new media. In this context traditional literacy transforms into digital literacy (DL) and the DL fits into the frames of the information society (IS) defined as "the new status quo and the new socio-economic and technological paradigm likely to occur because of the current all-embracing process of change. It is expected to affect the interaction in computer- mediated human activities, individual human behavior, the collective consciousness, and the economic and social environment (...). The emergence of the Information Society signifies the transition toward a new form of society based on the production and exchange of information (...). Its evolution is likely to introduce new virtual spaces (...) and a whole range of computer-mediated human activities" (Stary, 1999, p. 2).

Due to this definition of IS, it is worth emphasizing a few terms: computer-mediated, virtual spaces, and of course exchange of information. Such phrases indicate that sending and spreading information in a form of a codex, id. printed book with binding cover, cannot be the goal of "the current all-embracing process of change". Furthermore, the overwhelming popularity of such projects and ideas as Google Books, open access, and of course new media with its digitality, interactivity, hyper textuality and virtuality (Lister, et al., 2009, pp. 14-34) may announce the end of the codex book and traditional publishing.

As Lloyd Davidson, the Life Sciences Librarian and Bibliographer, pointed out, "The digital publication has suddenly become the copy of the record and those few print copies that remain merely provide a lingering convenience for those who, like me, haven't yet been willing to cut the ties to print entirely' (Davidson, 2005). So from this perspective publishing books (newspaper, magazine ${ }^{1}$ and so on) in printed form seems to be a custom which sooner or later will be fading out, unless those who "haven't yet been willing to cut the ties to print entirely" will still exist.

\section{Main questions of the paper-some data and remarks}

The crucial question for the presented paper is if printed (codex) book and its reading mean a form of distributing texts 


\title{
International Journal of Business and Social Science Research
}

\author{
Vol: 2, Issue: 12 \\ December/2021 \\ DOI: http://dx.doi.org/10.47742/ijbssr.v2n12p2 \\ https://ijbssrnet.com/index.php/ijbssr
}

which will be progressively declining under pressure the digital books have any features which cannot be replaced by online revolution (Q1). To answer this question, it is necessary to publishing (Q2). In the second question, one should take into describe the current situation of traditional printing and also raise account the cultural and subjective context of reading or the question of printed documents especially printed and codex possessing printed books

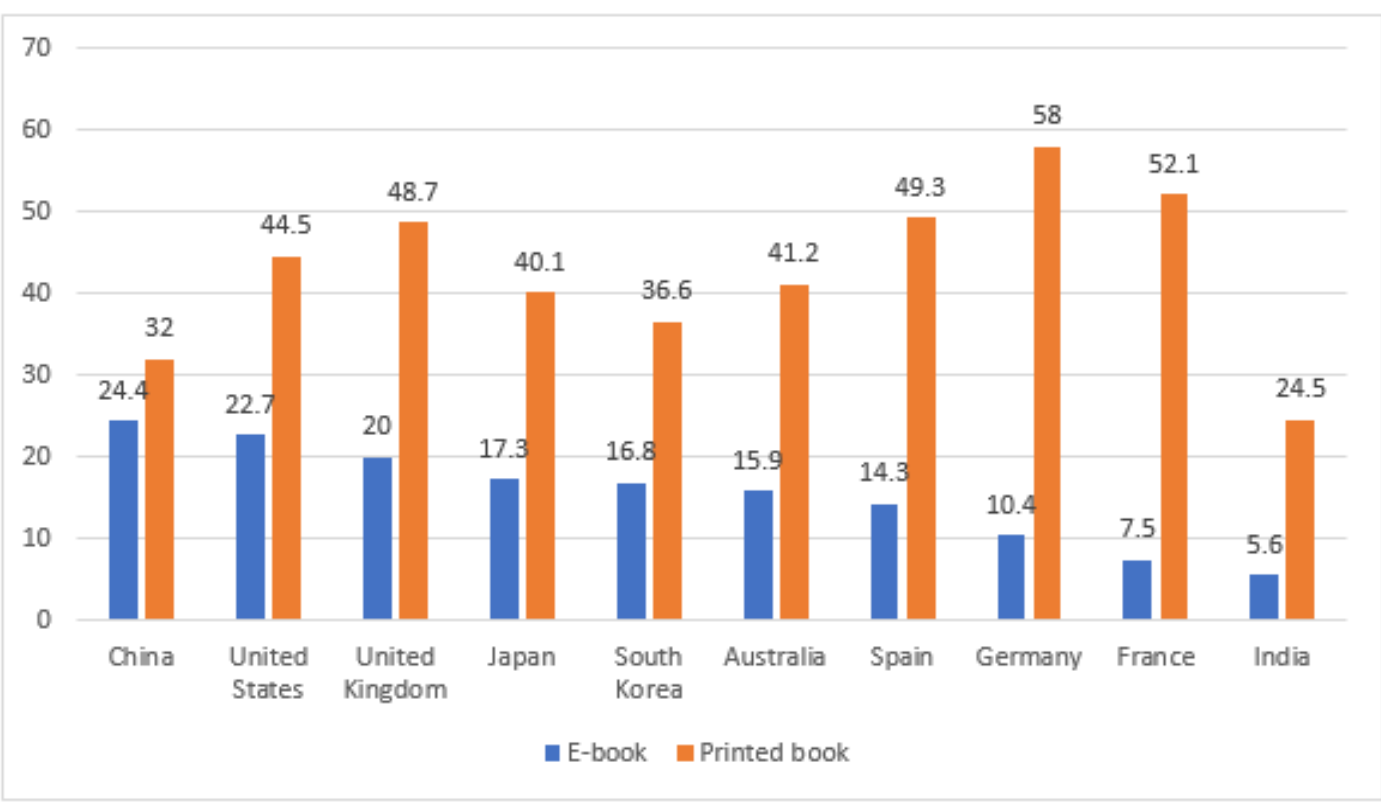

Figure 1. Estimated share of the population that purchase an e-book/ a printed book in 2020 (in percentage) Source: (Richter, 2021)

Figure 1 clearly shows that printed books are still popular and theirs share in the publishing market is up to five times (see Germany) or even seven times bigger (France) than e-books'. It is also worth noting that the data covers the year 2020 i.e. the period when the covid pandemic overflew the world, the most countries entered restrictions and almost the whole life moved into the internet. Such circumstances may cause that using online documents (e-books and so on) probably is more convenient, but on the other side choosing the real, solid book might be interpreted as a counterreaction to the "online life" during the pandemic. This possibility of different, sometimes even contradictory explanations of the given phenomenon will be discussed in later paragraphs.

Another data from the USA one of the leaders in new, digital media demonstrates, that "the end printed books" should be regarded with caution. "Despite some growth in certain digital formats, it remains the case that relatively few Americans only consume digital books (which include audiobooks and e-books) to the exclusion of print. Some $37 \%$ of Americans say they read only print books, while $28 \%$ read in these digital formats and also read printed books. Just $7 \%$ of Americans say they only read books in digital formats and have not read any printed books in the past 12 months (Perrin, 2019).

In the case of European countries, "the e-book market (now nearing $10 \%$ of the total) showed signs of stagnation for the last 5 years (but it could be a matter of capturing the right data), whereas audiobook sales exploded in 2019, giving new impetus to digital sales. If 2018 marked a trend reversal in the recovery process started in 2015, 2019 confirmed the positive trend" (Federation of European Publishers, 2021).
As a side note, it is worth discussing the growing popularity of audiobooks stressed in both cited surveys. Usually, digitalization and new media are deeply connected with image, their visual aspect is held as the most important one. But the mentioned facts clearly show that the pure audial sphere plays a relevant role also in digital reality.

This illustrative data review will be closed by an example from the Polish book market, which was chosen because of two reasons. Firstly, it could be taken as a sample of the typical postcommunist market, secondly, the author of the presented paper for years has been working as an editor for different publishing houses and knows this market from the publishers' side. In the functioning of Polish book market interesting is the ratio of paper books to e-books' titles. There is a tendency to level off the ratio between these two versions of one title, but it still does not relate to belles-lettres, teenagers' literature, horrors, and children's books (Drózd, 2020). The beginning of the e-books market in Poland met a few obstacles. One of the major was connected with the status of intellectual property and very popular conviction, that if something was published on the internet is for free and a lot of authors worried about the benefits. It is important to stress that this belief is regarded as obvious not only among Polish or other post-communist citizens but has probably a universal character (Reuß, 2017, p. 10).

Invoked data and processes observed in the publishing market allow us to state that at the present almost twenty years of open access project there is no fading out of printed, codex books. So the answer for the first question (Q1) in the presented research is "no" the digital revolution doesn't shatter or even weaken the position of solid books and traditional publishing (at least as before). 


\title{
International Journal of Business and Social Science Research
}

\author{
Vol: 2, Issue: 12 \\ December/2021 \\ DOI: http://dx.doi.org/10.47742/ijbssr.v2n12p2 \\ https://ijbssrnet.com/index.php/ijbssr
}

\section{Two scenarios}

In reflection on the condition of traditional books in the digital area, it can be observed the tendency to figure out different scenarios for the future of printed publications. The Polish Book Institute developed two scenarios directly focused on the topic ${ }^{2}$. The first one, called "the vinyl record scenario" states, that solid books, published by the professional editors, would be something special, addressed to a narrow range of consumers, "bookophile" individuals just as it happens with vinyl records and the niche of audiophiles (Print Partner, 2015) ${ }^{3}$. It should be mentioned that the analogy between the printed book and vinyl record is an approximation. As Ronald Reuß, professor of edition philology pointed out, in phonographic records, there is no difference between original file and copy, but in publishing is not the same situation, because fonts, theirs type size and even baseline designed by the editor could not be presented in the device which is used to read (Reuß, 2017, pp. 8-9).

The second scenario and the worst one show the world without books at all (Print Partner, 2015). The reason for such a world may be summarized in one word: "fast". Doing something as quickly as possible or being less time-consuming could be taken as a cliché of communication in the digital period (Print Partner, 2015). New media and big data form the one side, and from the other information overload this is not a good background for carefully studying linear and deprived of any hyperlinks printed book. It seems so obvious but there is a simplification which will be later discussed.

\section{The wrong dilemma}

In these two scenarios, the digital revolution is presented as an antithesis to the "Gutenberg Galaxy" (Marshall McLuhan) with typography and printing as one of the key elements, but probably the relation between these two historical movements is not like an exclusive disjunction, where the only one value can be true. It is more like a logical alternation both the digital world and Gutenberg Galaxy have common parts, but also some features differ in these paradigms.

Although at first glance digital revolution seems to be an opposition to the printing culture, because the former is connected with being virtual, non-material, or fluent and the latter's products have material and tactile characteristics that can coexist. Studying human phenomena shows that the unity of contradictions is quite common. The complexity of post-industrial time leads to the situation when the Hegelian dialectic seems to be the quite useful explanatory model for instance it is seen in the connection between globalization and indigenous cultures where both find their synthesis or hybrid (mixed) form in glocalization (Pirveli \& Lewczuk, 2013, p. 47)

Contradictory, mixed, or hybrid features of contemporary human reality were stressed by Lev Manovich in the preface to the Polish edition of his fundamental book The Language of New Media (Manovich, 2006, p. 15). From this perspective, the dilemma: digital or printed with classical tertium nondatum simply is not a method to grasp the publishing market of our times. Digital documents and codex, printed books seem to be a complementary form of readership. There is no strict opposition between the both because traditional books have some features which so far can't be replaced one to one by digital form. It was previously mentioned that fonts, their type size, and baseline designed by the editor could not be respected by the device used to read. In addition, paper sheets in books have specific sizes, weight, coat, and brightness which usually can't be represented on any screen. Another important aspect of a traditional book is the resolution of paper which is much higher than any screen resolution (Reuß, 2017, p. 11).

Details listed above of printed books belong to those which cannot be replaced by online publishing (Q2). They have technical nature. Besides such features, there are also ones that have psychological and sociological character. Using any device connected to the Internet what is normal in reading digital documents is quite good in so-called extensive reading. In this kind of reading essential is to grasp the main information without studying the language structure, style, levels of meaning, "texture" especially in poetry. Another type of reading, far from "flattening attention" (Reuß, 2017, p. 11), is an intensive reading which easier to perform with the traditional book than online - in the second case temptation to browse something else (another text, page, film and so on) is quite strong and plays a role in diffuse someone's attention.

From the sociological point of view, a traditional book has a symbolic meaning, which is unique to the physical book. Possessing a home library or even traveling with the printed book can be read as a symbol of highbrow status or aspirations. While watching TV news one can notice that professional comments on the current issue given by specialists are broadcasting with the bookcase in the background. It could be interpreted as a metonymy of being objective, scientific, or even wise.

\section{Conclusions-the third way}

Technical, psychological, and sociological features of the traditional book allow concluding that even during the digital revolution printed materials still play an important role. What in the end should be stressed, interpreting digital culture as opposed to traditional publishing is a kind of simplification? As it was demonstrated statistical data from the publishing market, the mixed or hybrid character of postmodern reality and mentioned features of printed books are conditions to draw the third scenario for the Gutenberg Galaxy during the time of big data and open access. This third way means complementary coexisting of these paradigms (PwC, 2015, p. 15).

The third scenario with the complementary relationship between traditional publishing and e-books is deeply connected with the observation that because of the digital revolution reading practice has two forms: traditional and digital. Theirs coexisting was called above hybrid reading. This state of affairs has equivalent in the functioning of publishing market sales cycles of digital texts are different from print book producing, delivery, and selling process (Nowell, 2015). They simply satisfy or meet different needs but "different" doesn't mean "opposite" 
Vol: 2, Issue: 12

December/2021

DOI: $\underline{\text { http://dx.doi.org/10.47742/ijbssr.v2n12p2 }}$

https://ijbssrnet.com/index.php/ijbssr

\section{Bibliografia}

Davidson, L., 2005. The End of Print: Digitization and Its Consequence-Revolutionary Changes in Scholarly and Social Communication and in Scientific Research. International Journal of Toxicology, 1 January, 24(1).

Drózd, R., 2020. Podsumowanie roku 2019: rynek e-booków w Polsce, s.1.: Świat Czytników.

Federation of European Publishers, 2021. European Book Publishing Statistics 2019, s.1.: The Voice of European Publishers.

Jones, N., 2018. 11 Digital Transformation Quotes To Lead Change \& Inspire Action, s.1.: s.n.

Lister, M. et al., 2009. New Media: A Critical Introduction. Oxon: Routledge.

Manovich, L., 2006. Język nowych mediów. Warszawa: Wydawnictwa Akademickie i Profesjonalne.

Nowell, J., 2015. The Changing Mix of What Sells in Print, s.1.: Nielsen Book.

Pepitone, J., 2012. Encyclopedia Britannica to stop printing books, s.l.: s.n.

Perrin, A., 2019. One-in-five Americans now listen to audiobooks, s.1.: Pew Research Center.

Pirveli, M. \& Lewczuk, B., 2013. Geografia i skala glokalna - przemiana generacyjna. Annales Universitatis Mariae Curie-Skłodowska, LXVIII(2), pp. 41-58.

Print Partner, 2015. Doskonałość w poligrafii. [Online] Available at: http://www.print-partner.com.pl/print_pub/publik/2015/przyszlosc-ksiazki-drukowanej.html

[Accessed 1809 2021].

PwC, 2015. Turning the Page: The Future of eBooks, s.1.: PwC.

Reuß, R., 2017. Perfekcyjna maszyna do czytania. O ergonomii ksiażki. Kraków: d2d.pl.

Richter, F., 2021. E-Books Still No Match for Printed Books, s.l.: s.n.

Stary, C., 1999. Toward an Information Society for All: HCI challenges and R\&D recommendations. International Journal of Human-Computer Interaction, 11(1), pp. 1-28.

Thompson, J. B., 2021. Book wars: The Digital Revolution in Publishing. s.1.:Polity.

TonnerBuzz, 2021. Paper Books vs eBooks Statistics, Trends and Facts [2021], s.1.: s.n. 